\title{
Postupci za procenu rizika od požara
}

$\mathrm{P}$ rema članu 42 Zakona o zaštiti od požara [10] i članu 8 Pravilnika o načinu izrade i sadržaju Plana zaštite od požara autonomne pokrajine, jedinice lokalne samouprave i subjekata razvrstanih u prvu i drugu kategoriju ugroženosti od požara [12], u našoj državi je uvedena obavezna procena požarnog rizika za vrlo široke klase objekata. U svetu je razvijeno više postupaka namenjenih analizi požarnih rizika.

\section{1}

\section{Uvod}

Prvi grupa postupaka za procenu požarnog rizika nastala je na osnovu istraživanja švajcarskog inženjera Maksa Gretenera koja su izvršena u periodu od 1961. do 1968. godine. Gretener je na osnovu dobijenih podataka formulisao postupak za procenu požarnog rizika i definisao preporuke za uvođenje minimalnih preventivnih mera zaštite od požara, u zavisnosti od požarnog rizika. Gretenerov postupak je modifikovan na više načina. Jednu verziju je standardizovalo Švajcersko udruženje osiguravajućih kompanija u saradnji sa Švajcerskim udruženjem inžnjera i arhitekata pod nazivom SIA 81 (ta verzija se obično naziva Gretenerov postupak) čija je najnovija verzija SIA 2007 objavljena 2007 godine, a drugu Austrijski vatrogasni savez pod nazivom Tehnička preporuka TRVB 100 (prva verzija objavljena 1975, aktuelna 1987. godine). Modifikaciju koja se po proračunskoj proceduri bitno razlikuje od prethodne dve razvila je za svoje European Fire Alarm Manufacturers Association. Ona je poznata kao Euroalarmov postupak. U Belgiji je razvijena četvrta modifikacija poznata kao FRAME (Fire Risk Assessment Method for Engineering) 1988. godine. Njene nove verzije su definisane 1999. i 2008. godine. Poslednja verzija FRAMEa je usklađena sa metodologijom na kojoj se baziraju Evropske norme koje definišu bezbednost mašina EN 954-1 i EN 14121-1:2007.

Druga grupa postupaka ima cilj da proceni minimalnu neophodnu otpornost građevinske konstrukcije prema požaru. Prvi od njih je razvio švajcarac E. Gelinger, 1950. godine, za industrijske objekte sa metalnom konstrukcijom. Njegov postupak je proširio nemački inženjer V. Halpap za ostale industrijske objekte. Halpapov postupak je standardizovan 1964. godine u obliku standarda DIN18230. U našoj državi taj standard je preveden u obliku SRPS TR19:1997 [14]. Nove verzije standarda DIN18230 (sa proširenim tablicama) su objavljene 1998. i 2010. godine. U našoj državi je 2012. usvojen standard SRPS-EN1991-1-2:2012 [18] u kojem je modifikovana Halpapova proračunska procedura. Taj standard pripada klasi Eurokodovih standarda. Za određivanje neophodne otpornosti prema požaru stambenih, poslovnih i javnih zgrada, kod nas se za objekte niže od 22 m standardno koristi Tehnička preporuka SRPS TP21:2003 [1415.
Napomenimo da je tehničke preporuke SRPS TR19:1997 i SRPS TP21:2003 Institut za standardizaciju Srbije povukao 21. septembra 2016.

\section{Specifično požarno opterećenje}

Ukupno požarno optrećenje građevinskog objekta, ili njegovog dela, je toplotna energije koja se može osloboditi u požaru, prilkom njegovog potpunog sagorevanja. Prilikom proračuna se uzimaju u obzir svi gorivi materijali u smislu standarda SRPS U.J1.020, koji su sastavni deo objekta instalacija, opreme i materijala za koji je objekat namenski izgrađen. Specifično požarno opterećenje je količnik ukupnog požarnog optrećenja i površine prostora za koji se ono izračunava. Proračun specifičnog požarnog opterećenja prostorija vrši se u skladu sa SRPS U.J1.030:1976 [16], koji je obavezan za primenu prema Pravilniku o tehničkim i drugim zahtevima za utvrđivanje požarnog opterećenja i stepena otpornosti prema požaru [11]. Prema citiranom standardu za njegovo izračunavanje se koristi formula:

$$
P=\sum_{i} \frac{V_{i} \cdot H_{i} \cdot \rho_{i}}{S}
$$

gde je:

$\mathrm{P}$ - specifično požarno opterećenje $\mathrm{u}\left[\mathrm{MJ} / \mathrm{m}^{2}\right]$,

pi - gustina materijala u $\left[\mathrm{kg} / \mathrm{m}^{3}\right]$,

$\mathrm{Vi}$ - zapremina materijala $\mathrm{u}\left[\mathrm{m}^{3}\right]$,

$\mathrm{S}$ - površina osnove $\mathrm{u}\left[\mathrm{m}^{2}\right]$,

$\mathrm{Hi}$ - donja toplotna moć materije u $[\mathrm{MJ} / \mathrm{kg}]$,

$\mathrm{i}$ - indeks elementarne jedinice.

Citiranim standardom određuju se tri kategorije specifičnog požarnog opterećenja:

- $\quad$ nisko požarno opterećenje do $1 \mathrm{GJ} / \mathrm{m}^{2}$;

- $\quad$ srednje požarno opterećenje od $1 \mathrm{GJ} / \mathrm{m}^{2}$ do $2 \mathrm{GJ} / \mathrm{m}^{2}$;

- $\quad$ visoko požarno opterećenje preko $2 \mathrm{GJ} / \mathrm{m}^{2}$.

U objektima koji sadrže osnovne jedinice sa različitim kategorijama požarnog opterećenja ne izračunava se specifično požarno opterećenja za ceo objekat. U takvim objektima potrebno je posebno navesti površine koje spadaju u pojedine kategorije, i za njih izračunati specifično požarno opterećenje.

Svaki od nabrojanih postupaka (Euroalarmov, Gretenerov, FRAME i TRVB 100) zasebno definišu pojmove pokretno specifično požarno opterćenje (potiče od gorivog sadržaja objekta) i nepokretno specifično požarno opterćenje (potiče od gorivih materijala ugrađenih 
u konstrukciju objekta - pri čemu se izuzima fasada objekta i spoljna stolarija). Za određivanje pokretnog opterećenja koriste se tablice koje se razlikuju za svaku od metoda. U Tabeli 1. je dato nekoliko primera iz kojih se vidi da između tablica mogu da budu veoma značajne.

Tabela 1. Pokretna specifična požarna opterećenja

\begin{tabular}{|l|c|c|c|c|}
\hline Namena objekta & $\begin{array}{c}\text { SIA } \\
{\left[\mathbf{M J} / \mathbf{m}^{\mathbf{2}}\right]}\end{array}$ & $\begin{array}{c}\text { TRVB 100 } \\
{\left[\mathbf{M J} / \mathbf{m}^{\mathbf{2}}\right]}\end{array}$ & $\begin{array}{c}\text { Euroalarm } \\
{\left[\mathbf{M J} / \mathbf{m}^{2}\right]}\end{array}$ & $\begin{array}{c}\text { FRAME } \\
{\left[\mathbf{M J} / \mathbf{m}^{\mathbf{2}}\right]}\end{array}$ \\
\hline Autolakirnica & 293 & 500 & 167 & 2000 \\
\hline $\begin{array}{l}\text { Automehaničarski } \\
\text { servis }\end{array}$ & 335 & 300 & 335 & 1500 \\
\hline Montaža automobila & 544 & 300 & 335 & 1500 \\
\hline Stambeni prostor & 125 & 300 & 335 & 500 \\
\hline Antikvarnica & 168 & 700 & 670 & 500 \\
\hline Arhiva & 335 & 12600 & 4187 & 600 \\
\hline
\end{tabular}

Prilkom procene nepokretnog specifičnog požarnog opterećenja po Euroalarmu procena se vrši prema Standardu SRPS U.J1.030:1976 [16]. TRVB 100 deli objekte u 14 kategorija koje zavise između ostalog: od starosti, tipa građevinske konstrukcije, načina izgradnje,... Za svaku od tih kategorija usvojeno je konkretno nepokretno specifično požarno opterećenje. FRAME razlikuje 6 tipova oblika a Gretenerov postupak 18 tipova neindustrijskih objekata i 30 vrsta industrijskih objekata, i slično kao u TRVB 100 za svaki tip usvoja se iznos nepokretnog specifičnog požarnog opterećenja. Napominjemo da se prilikom primene Gretenerovog postupka i TRVB 100 mogu dobiti različiti rezultati. Iskustava autora govore da su razlike manje nego kod procena pokretnog opterećenja.

Prilikom procenjivanja specifičnog požarnog opterećenja mora se izabrati jedna metoda i ona primenjivati prilikom celog proračuna, to je jest ne smeju se kombinovati procedure i tablični podaci iz različitih metoda. Na to nas obavezuje član 8 Pravilnika [12].

\section{Stepen otpornosti prema požaru}

Stepen otpornosti prema požaru (SOP) se određuje prema standardu SRPS U.J1. 240:1994 [17], koji je obavezan za primenu prema Pravilniku o tehničkim i drugim zahtevima za utvrđivanje požarnog opterećenja i stepena otpornosti prema požaru (Službeni glasnik Republike Srbije broj 74/2009) [11]. Prema citiranom standardu objekat ili deo objekta može imati sledeće stepene otpornosti prema požaru:

$$
\begin{aligned}
& \text { I stepen - neznatna otpornost (bez otpornosti) - NO } \\
& \text { II stepen - mala otpornost }- \text { MO } \\
& \text { III stepen - srednja otpornost }- \text { SO } \\
& \text { IV stepen - veća otpornost }- \text { VO } \\
& \text { V stepen - velika otpornost }- \text { WO }
\end{aligned}
$$

\begin{tabular}{|c|c|c|c|c|c|c|c|}
\hline \multirow[t]{2}{*}{$\begin{array}{c}\text { Vrsta } \\
\text { konstrukcije }\end{array}$} & \multirow[t]{2}{*}{ SRPS } & \multirow[t]{2}{*}{ Položaj } & \multicolumn{5}{|c|}{$\begin{array}{l}\text { Stepen otpornosti prema } \\
\text { požaru } \\
\text { Vatrootpornost konstrukcije [h] }\end{array}$} \\
\hline & & & I & II & III & IV & V \\
\hline Nosivi zid & U.J1.090 & \multirow{6}{*}{$\begin{array}{l}\text { Unutar } \\
\text { požarnih } \\
\text { sektora }\end{array}$} & $1 / 4$ & $1 / 2$ & 1 & 1,5 & 2 \\
\hline Stub & U.J1.100 & & $1 / 4$ & $1 / 2$ & 1 & 1,5 & 2 \\
\hline Greda & U.J1.114 & & - & $1 / 4$ & $1 / 2$ & 1 & 1,5 \\
\hline $\begin{array}{l}\text { Međuspratna } \\
\text { konstrukcija }\end{array}$ & U.J1.110 & & - & $1 / 4$ & $1 / 2$ & 1 & 1,5 \\
\hline Nenosivi zid & U.J1.090 & & - & $1 / 4$ & $1 / 2$ & $1 / 2$ & 1 \\
\hline Krovna konstrukcija & - & & - & $1 / 4$ & $1 / 2$ & $1 / 2$ & 1 \\
\hline Zid & U.J1.092 & \multirow{5}{*}{$\begin{array}{l}\text { Na granici } \\
\text { požarnih } \\
\text { sektora }\end{array}$} & $1 / 4$ & 1 & $11 / 2$ & 2 & 3 \\
\hline $\begin{array}{l}\text { Međuspratna } \\
\text { konstrukcija }\end{array}$ & U.J1.110 & & $1 / 4$ & $1 / 2$ & 1 & 1,5 & 2 \\
\hline $\begin{array}{l}\text { Vrata i klapne } \\
\text { do } 3.6 \mathrm{~m}^{2}\end{array}$ & U.J1.160 & & $1 / 4$ & $1 / 4$ & $1 / 2$ & 1 & 1,5 \\
\hline $\begin{array}{l}\text { Vrata veća } \\
\text { od } 3.6 \mathrm{~m}^{2}\end{array}$ & U.J1.160 & & $1 / 4$ & $1 / 2$ & 1 & 1,5 & 2 \\
\hline $\begin{array}{l}\text { Konstrukcija } \\
\text { evakuacionog puta }\end{array}$ & - & & $\begin{array}{l}\text { Negorivi } \\
\text { materijali }\end{array}$ & $1 / 2$ & $1 / 2$ & 1 & 1,5 \\
\hline Fasadni zid & U.J1.092 & \multirow{2}{*}{$\begin{array}{c}\text { Spoljna } \\
\text { konstrukcija }\end{array}$} & - & $1 / 2$ & $1 / 2$ & 1 & 1 \\
\hline Krovni pokrivač & U.J1.140 & & - & $1 / 4$ & $1 / 2$ & $3 / 4$ & 1 \\
\hline
\end{tabular}

Napominjemo, da bi se izbegle eventualne zabune, da je postojala predhodna verzija tog standarda koja se označavala sa JUS U.J1.240:1981, koja se u nekim zahtevima razlikovala od aktuelne.
Tabela 2. Stepen otpornosti prema požaru

Usklađivanje stepena otpornosti prema požaru zgrade prema pojedinim vrednostima otpornosti prema požaru njenih kostrukcionih elemenata vrši se na osnovu podataka iz prethodne tabele. Ako zgrada ili njen požarni segment ima pojedine građevinske konstrukcije sa otpornošću većom ili jednakom onoj naznačenoj u tabeli za pojedini stepen otpornosti, a samo jedna konstrukcija ima tu vrednost manju od naznačene, zgrada ima onaj stepen otpornosti koji odgovara toj manjoj vrednosti. Ako se zgrada sastoji iz više konstrukcionih celina požarno izdvojenih (požarni segmentu), pri čemu postoje različiti stepeni otpornosti prema požaru, kad je potrebno da se izrazi stepen otpornosti za ceo objekat, zgrada ima onaj stepen otpornosti koji ima požarni segment sa najmanjim stepenom otpornosti.

Prilikom određivanja požarnih rizika koristi se vatrootpornost konstrukcije koja se koja se izražava u minutima i označava sa F. Standardne vatrootpornosti su F15, F30, F60 i F90 i F120. Oznaka F60 praktično znači da se deo objekta na koji se odnosi, neće srušiti posle 60 minuta požara, niti će se požar preneti iz tog dela objekta. Vatrootpornost se određuje za svaki od elemenata konstrukcije prema standardmima, datim u drugoj koloni Tabele 2. Možemo usvojiti da otpornost $<$ F30 približno odgovara I stepenu, F30 približno odgovara II stepenu, F60 približno odgovara III stepenu, a F90 približno odgovara IV i V stepenu. Napominjemo da takva klasifikacija nije sasvim u skladu sa našim propisima. 


\section{PT Tehnički propisi}

\section{$4 \quad$ Gretenerov postupak}

Osnovna Gretenerova formula je

$R=B \cdot A=\frac{P \cdot A}{N \cdot S \cdot F}$

gde je:

$\mathrm{R}$ - koeficijent požarnog rizika;

B - koeficijent požarne opasnosti;

A - koeficijent mogućnost izbijanja požara;

$\mathrm{P}$ - koeficijent potencijalnog rizika;

$\mathrm{N}$ - koeficijent standardnih mera zaštite;

$\mathrm{S}$ - koeficijent posebnih mera zaštite; i

F- koeficijent vatrootpornosti objekta.

Koeficijent potencijalnog rizika zavisi od: specifičnog požarnog opterećenja, zapaljivosti, površine ugroženog sektora i mogućnosti prenošenja požara iz njega, mogućnost zadimljavanja i korozije, kao i visine objekta.

Parametri N i S zavise od opremljenosti i udaljenost vatrogasne jedinice, kao i postojanja stabilnih sistema za dojavu i gašenje požara.

$\mathrm{Na}$ početku primene proračuna se odredi privatljiva veličina koeficijenta požarnog rizika, pa se potom određuju neophodne mere zaštite tako da formula (2) bude ispunjena. Vrednosti koeficijenta $\mathrm{R}$ se kreću od 0,85 (najugroženiji objekti) do 1,30.

Ova metoda je našla velike primene u izračunavanju premije osiguranja.

\section{$5 \quad$ TRVB postupak}

Odluka o neophodnim protivpožarnim merama se donosi na osnovu izračunate vrednosti Faktora preventivnih protivpožarnih mera (SxF) i procenjene vrednosti otpornosti građevinske konstrukcije prema požaru (F). Za određivanje faktora $\mathrm{SxF}$ koristi se formula:

$$
S x F=\frac{(G+6,04) \cdot B}{8,33}
$$

ako je u objektu izveden sistem za odvođenje dima i toplote. U suprotnom se koristi formula:

$$
S \mathrm{xF}=\frac{(G+4,42) \cdot B}{6,25}
$$

$\mathrm{G}$ je faktor geometrije požarnog sektora. Ako je sektoru obezbeđen sa tri strane pristup za gašenje požara, to jest ako na zidovima koji ograničavaju požarni sektor na svakih $20 \mathrm{~m}$ postoji najmanje jedan otvor koji se može iskoristi za tu namenu onda je:

$$
G=\frac{a \cdot b}{10^{5}}
$$

U suprotnom se koristi formula:

$$
G=\frac{a \cdot b \cdot 1,5}{10^{5}}
$$

$\mathrm{U}$ obe formule je:

$$
\begin{aligned}
& \mathrm{a} \text { - površina požarnog sektora }\left[\mathrm{m}^{2}\right] \\
& \mathrm{b} \text { - širina požarnog sektora }[\mathrm{m}] .
\end{aligned}
$$

B je Faktor specifične opasnosti od požara koji se izračunava po formuli:

$$
B=Q \cdot C \cdot R \cdot K \cdot A \cdot P \cdot E \cdot H
$$

gde su:

E - Faktor intervencije vatrogasne jedinice;

A - Faktor požarne opasnosti;

P - Faktor ugroženost osoba;

Q - Faktor specifičnog požarnog opterećenja;

C - Faktor ugroženosti od požara;

R - Faktor opasnosti od zadimljena;

$\mathrm{K}$ - Faktor opasnost od korozije;

$\mathrm{H}$ - Faktor visine građevine.

Svi koeficijenti se određuju odgovarajućim procedurama.

Kao što smo istakli, odluka o neophodnim protivpožarnim merama se donosi na osnovu izračunate vrednosti Faktora preventivnih protivpožarnih mera $(\mathrm{SxF})$ i procenjene vrednosti otpornosti građevinske konstrukcije prema požaru (F). TRVB 100 metoda prepoznaje različite nivoe preventivnih mera zaštite od požara, koje su označene sa S1, S2, S3, S4 i S5 kao i njihove kombinacije. Zbog razlika u organizovanju vatrogasnih jedinica u našoj državi i Austriji, trenutno kod nas, nije moguća direktna primena mera koje nalaže TRVB 100. Zbog toga su u radu [1] predlažene sledeće klase preventivnih mera:

A - $\mathrm{u}$ toku radnog vremena obezbeđeno dejstvo profesionalne vatrogasne jedinice u roku od 10 minuta od dojave požara; $\mathrm{V}$ - celodnevno obezbeđeno dejstvo profesionalne vatrogasne jedinice u roku od 10 minuta od dojave požara;

$\mathrm{S}$ - instaliran automatski stabilan sistem za dojavu požara;

$\mathrm{S}$ - instaliran sprinkler sistem za gašenje požara.

Tabela 3. Neophodne preventivne mere

\begin{tabular}{|c|c|c|c|c|c|c|c|c|c|}
\hline $\mathbf{S x F}$ & $<\mathbf{F 3 0}$ & $\mathbf{F 3 0}$ & $\mathbf{F 6 0}$ & $\mathbf{F 9 0}$ & $\mathbf{S x F}$ & $<\mathbf{F 3 0}$ & $\mathbf{F 3 0}$ & $\mathbf{F 6 0}$ & $\mathbf{F 9 0}$ \\
\hline $0.0-1.0$ & - & - & - & - & $3.4-3.5$ & A,S,S & A,S & S & A,S \\
\hline $1.0-1.3$ & A & - & - & - & $3.5-3.6$ & A,S,S & A,S & S & A,S \\
\hline $1.3-1.4$ & A & A & - & - & $3.6-3.7$ & A,S S & A,S & A,S & A,S \\
\hline $1.4-1.6$ & S & A & - & - & $3.7-3.9$ & A,S,S & S,S & A,S & A,S \\
\hline $1.6-1.8$ & V & A & A & - & $3.9-4.0$ & A,S,S & A,S,S & A,S & A,S \\
\hline $1.8-1.9$ & V & S & A & A & $4.0-4.1$ & V,S & A,S S & A,S & A,S \\
\hline $1.9-2.0$ & A,S & S & A & A & $4.1-4.2$ & V,S & A,S,S & A,S & A,S \\
\hline $2.0-2.1$ & S & V & A & A & $4.2-4.4$ & $!$ & A,S,S & A,S & A,S \\
\hline $2.1-2.2$ & S & V & A & A & $4.4-4.6$ & ! & A,S,S & S,S & A,S \\
\hline
\end{tabular}


Tabela 3. Neophodne preventivne mere - nastavak

\begin{tabular}{|c|c|c|c|c|c|c|c|c|c|}
\hline $\mathbf{S x F}$ & $<\mathbf{F 3 0}$ & $\mathbf{F 3 0}$ & $\mathbf{F 6 0}$ & $\mathbf{F 9 0}$ & $\mathbf{S x F}$ & $<\mathbf{F 3 0}$ & $\mathbf{F 3 0}$ & $\mathbf{F 6 0}$ & $\mathbf{F 9 0}$ \\
\hline $2.2-2.4$ & S & V & S & A & $4.6-4.8$ & $!$ & A,S,S & A,S,S & A,S \\
\hline $2.4-2.5$ & A,S & V & S & A & $4.8-4.9$ & $!$ & V,S & A,S,S & A,S \\
\hline $2.5-2.6$ & A,S & A,S & V & S & $4.9-5.0$ & $!$ & V,S & A,S,S & A,S \\
\hline $2.6-2.8$ & A,S & S & V & S & $5.0-5.1$ & $!$ & V,S & A,S,S & S,S \\
\hline $2.8-2.9$ & A,S & S & V & S & $5.1-5.2$ & $!$ & $!$ & A,S,S & S,S \\
\hline $2.9-3.0$ & A,S & S & A,S & V & $5.2-5.6$ & $!$ & $!$ & A,S,S & A,S,S \\
\hline $3.0-3.1$ & S,S & A,S & A,S & V & $5.6-5.8$ & $!$ & $!$ & V,S & A,S,S \\
\hline $3.1-3.2$ & S,S & A,S & S & V & $5.8-6.3$ & $!$ & $!$ & $!$ & A,S,S \\
\hline $3.2-3.4$ & A,S,S & A,S & S & V & $6.3-6.5$ & $!$ & $!$ & $!$ & V,S \\
\hline
\end{tabular}

„-“ označava da nisu neophodne dodatne preventivne mere

„!“ označava da takav objekat ne sme da se projektuje

\section{$6 \quad$ Euroalarmov postupak}

Primenom Euroalarmovog postupka određuju se dva parametra: požarni rizik konstrukcije objekta i požarni rizik sadržaja objekta. Požarni rizik konstrukcije objekata zavisi od mogućeg intenziteta $i$ vremena trajanja požara, kao i konstruktivnih karakteristika nosivih elemenata objekta (otpornost konstrukcije prema delovanju visokih temperatura), izračunava se primenom obrasca:

$$
R_{o}=\frac{\left[\left(P_{o} \cdot C\right)+P_{k}\right] \cdot B \cdot L \cdot S}{W \cdot R_{i}}
$$

gde su:

R0 - požarni rizik konstrukcije objekta;

P0 - koeficijent pokretnog požarnog opterećenja;

C - koeficijent sagorljivosti sadržaja objekta;

$\mathrm{Pk}$ - koeficijent nepokretnog požarnog opterećenja;

B - koeficijent veličine i položaja požarnog sektora;

L - koeficijent kašnjenja početka gašenja;

S - koeficijent širine požarnog sektora;

W - koeficijent vatrotponosti konstrukcije;

Ri - koeficijent smanjenja požarnog rizika;

Svi koeficijenti se određuju odgovarajućim procedurama.

Požarni rizik sadržaja objekta (opasnost za ljude, opremu, nameštaj, uskladištenu robu i sl.) izračunava se na osnovu obrasca:

$$
R_{s}=H \cdot D \cdot F
$$

gde su:

H - koeficijent opasnosti po ljude;

D - koeficijent rizika imovine;

F - koeficijent delovanja dima;

$\mathrm{R}_{\mathrm{S}}$ - požarni rizik sadržaja objekta;
Svi koeficijenti se određuju odgovarajućim procedurama.

Na osnovu dobijenih rezultata donosi se odluka o neophodnosti primene nekih od preventivnih mera zaštite od požara. Euroalarm praktično razmatra dve takve mere:

1. ugradnju automatskog stabilnog sistema za gašenje požara;

2. ugradnju automatskog stabilnog sistema za dojavu požara.

Odluka o neophodnosti ugradnje stabilnih sistema tako što se za dobijene vrednosti požarnog rizika za objekat $\mathrm{R}_{0}$ (pri čemu se u ako je $\mathrm{R}_{0}<1$ uzima da je $\mathrm{R}_{0}=1$ ), kao i požarnog rizika sadržaja objekta $\mathrm{R}_{\mathrm{S}}$, određuje odgovarajuća tačka na dijagramu prikazanom na Slici 1 .

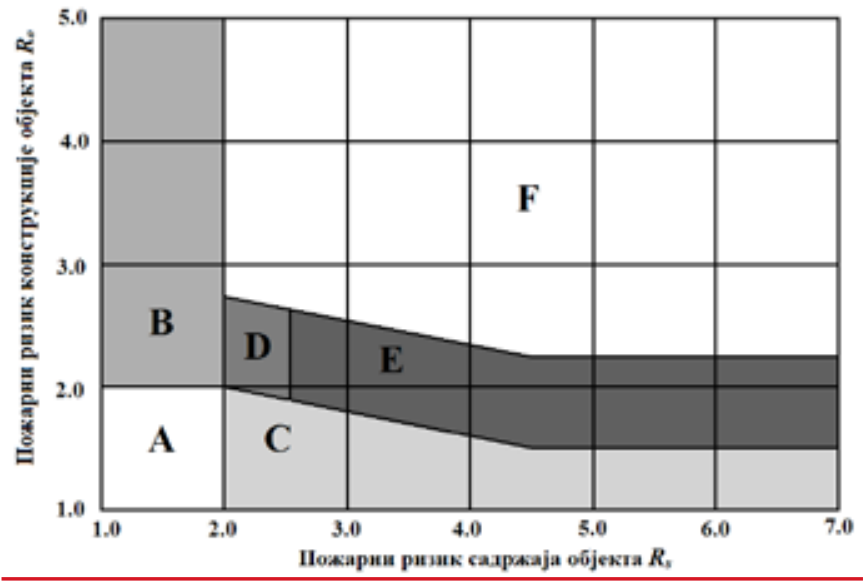

Slika 1: Euroalarmov dijagram

Ako se ona nađe u: oblasti A onda nije neophodna ugradnja stabilnih sistema za dojavu i gašenje požara; oblasti B onda nije neophodna ugradnja stabilnog sistema za dojavu a preporučuje se ugradnja stabilnog sistema za gašenje požara; oblasti C onda nije neophodna ugradnja stabilnog sistema za gašenje a preporučuje se ugradnja stabilnog sistema za dojavu požara; oblasti D onda je neophodna ugradnja stabilnog sistema za gašenje a preporučuje se ugradnja stabilnog sistema za dojavu požara; oblasti E onda je neophodna ugradnja stabilnog sistema za dojavu a preporučuje se ugradnja stabilnog sistema za gašenje požara; oblasti $\mathrm{F}$ onda je neophodna ugradnja stabilnog sistema za dojavu i ugradnja stabilnog sistema za gašenje požara. Ako se ona nalazi iznad dijagrama onda ugradnja stabilnog sistema za gašenje požara nije dovoljna nego se moraju primeniti dodatne preventivne mere, kao što su na primer zamena konstruktivnih elemenata u cilju podizanja stepena otpornosti prema požaru objekta ili formiranje odgovarajuće vatrogasne jedinice.

\section{$7 \quad$ Proračun prema SRPS TR19:1997}

Postupak je namenjen za određivanje neophodne otpornost konstrukcije prema požaru industrijskih objekata. Parametre neophodne za proračun dajemo u sledećoj tabeli: 


\section{PT Tehnički propisi}

Tabela 4. Parametri postupka

\begin{tabular}{|c|l|c|c|}
\hline RB & Parametar & Oznaka & Jedinica mere \\
\hline 1. & Proračunsko požarno opterećenje & $\mathrm{q}_{\mathrm{r}}$ & $\mathrm{kW} \cdot \mathrm{h} / \mathrm{m}^{2}$ \\
\hline 2. & Faktor sagorevanja & $\mathrm{m}_{\mathrm{i}}$ & - \\
\hline 3. & Kombinovana dopunska vrednost & $\psi_{\mathrm{i}}$ & - \\
\hline 4. & Ekvivalentno vreme trajanja požara & $\mathrm{t}_{\mathrm{a}}$ & $\mathrm{min}$ \\
\hline 5. & Faktor preračunavanja & $\mathrm{C}$ & $\mathrm{min} \cdot \mathrm{m}^{2} / \mathrm{kW} \cdot \mathrm{h}$ \\
\hline 6. & Faktor odvođenja toplote & $\omega$ & - \\
\hline 7. & Sigurnosna dopunska vrednost & $\mathrm{V}$ & - \\
\hline 8. & Dodatna vrednost & $\mathrm{V}_{\mathrm{nb}}$ & - \\
\hline 9. & Otpornost građevinske konstrukcije & $\mathrm{erf}_{\mathrm{F}}$ & $\mathrm{min}$ \\
\hline
\end{tabular}

Proračunsko požarno opterećenje se određuje primenom formule:

$q_{r}=\sum_{i} \frac{M_{i} \cdot H_{i} \cdot m_{i} \cdot \psi_{i}}{S}$

gde je:

$\mathrm{q}_{\mathrm{r}}$ - proračunsko požarno opterećenje $\mathrm{u} \mathrm{kW} \cdot \mathrm{h} / \mathrm{m}^{2}$,

$\mathrm{H}_{\mathrm{i}}$ - donja toplotna moć materije $\mathrm{u} \mathrm{kW} \cdot \mathrm{h} / \mathrm{m}^{3}$,

$\mathrm{M}_{\mathrm{i}}$ - masa materijala u $\mathrm{kg}$,

$\mathrm{S}$ - površina osnove $\mathrm{u}^{2}$,

$\mathrm{m}_{\mathrm{i}}$ - faktor sagorevanja,

$\psi_{\mathrm{i}}$ - kombinovana dopunska vrednost,

$\mathrm{i}$ - indeks elementarne jedinice.

Faktor sagorevanja uzima vrednosti između 0,2 i 1 . U SRPS TP 19:1997 su njegove vrednosti date u posebnom aneksu. U Nemačkoj je 2010 godine donet nova standard DIN18230 -3 u kojoj su date vrednosti faktora sagorevanja uslađene sa aktuelnim eksperimntalnim rezultatima. Faktor preračunavanja zavisi od karakteristika građevinskih materijala ugrađenih u konstrukciju sektora a faktor odvođenja toplote od karakteristika ventilacije prostora. Ekvivalentno vreme trajanja požara se izračunva prema formuli:

$$
t_{a}=q_{r} \cdot c \cdot \omega
$$

a proračunska otpornost građevinske konstrukcije prema formuli:

$$
\operatorname{erf} \mathrm{t}_{\mathrm{F}}=t_{a} \cdot \gamma \cdot \gamma_{n b}
$$

U zavisnosti od dobijene vrednosti određuje se minimalano vreme otpornosti konstrukcije prema požaru:

Tabela 5. Minimalano vreme otpornosti konstrukcije prema požaru

\begin{tabular}{|c|c|c|c|}
\hline RB & erf $\mathbf{t}_{\mathbf{F}}(\mathbf{m i n})$ & $\begin{array}{c}\text { Vreme otpornosti konstrukcije } \\
\text { prema požaru }\end{array}$ & klasa \\
\hline 1 & 15 & bez zahteva & - \\
\hline 2 & $15-30$ & $30 \mathrm{~min}$ & $\mathrm{~F} 30$ \\
\hline 3 & $30-60$ & $60 \mathrm{~min}$ & $\mathrm{~F} 60$ \\
\hline 4 & $60-90$ & $90 \mathrm{~min}$ & $\mathrm{~F} 90$ \\
\hline 5 & $90-120$ & $120 \mathrm{~min}$ & $\mathrm{~F} 120$ \\
\hline
\end{tabular}

8

\section{Skladišta}

Za skladišne objekte stepen otpornosti prema požaru je definisan Pravilnikom o tehničkim normativima za zaštitu skladišta od požara i eksplozija (Službeni list SFRJ 24/87), koji propisuje primenu sledeće tabele:

Tabela 6. Minimalano vreme otpornosti konstrukcije skladišta prema požaru

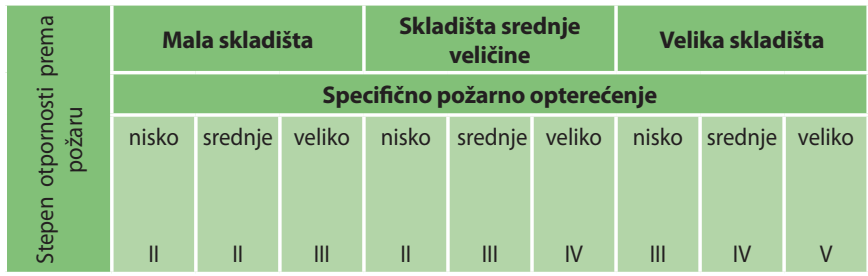

Prema citiranom pravilniku skladišta se dele na skladišta mala (površine do $1000 \mathrm{~m}^{2}$ ), srednje (površine od 1000 do $3000 \mathrm{~m}^{2}$, kao i sva regalna skladišta površine do $3000 \mathrm{~m}^{2}$ ) i velike (površine preko $3000 \mathrm{~m}^{2}$ kao i sva visoko-regalna skladišta).

\section{Zaključak}

Procena požarnih rizika prilikom donošenja odluka o ugradnji stabilnih sistema za dojavu i gašenje požara, je u našoj državi postala zakonska obaveza. Kod nas su u tu svrhu do sada najčešće koristio Euroalarmov postupak, koji smo detaljno izložili u ovom radu. Međutimu nekim slučajevima taj postupak može da nas ostavi u nedoumici prilikom donošenja odluke o ugradnji stabilnih sistema. To su slučajevi kada proračunska tačka pripada nekoj od oblasti koje su na Slici 1. označene sa B, C, D i E, ili se nalazi na granici dve oblasti. Zbog toga se preporučuje da se izvrši provera dobijene preporuke još jednom od relevantnih metoda. U radu [1] je kao predlog za komparativnu metodu izabrana Tehnička preporuka Austrijskog vatrogasnog saveza pod TRVB 100. Ta metoda se ne može direktno primeniti u našim uslovima zbog razlika u organizovanju vatrogasnih jedinica u našoj državi i Austriji. Pored toga ona se ne primenjuje na objekte više od $22 \mathrm{~m}$.

U Tabeli 3, koja je preuzeta iz rada [1] je izložena preporuka za prilagođavanje preventivnih mera koje nalaže TRVB 100, našim konkretnim uslovima. Prilikom formiranja tabele u svim ne definisanim slučajevima predlagane su strožije mere. Zbog toga, u nekim slučajevima koji su prema TRVB 100 dozvoljeni, nismo preporučili projektovanje objekta.

Za objekate visine između $22 \mathrm{~m}$ i $30 \mathrm{~m}$, kao komparativna metoda može se koristiti Gretenerov postupak (SIA 2007) ili FRAME 2008.

\section{Literatura}

[1] Aranđelović I., R. Rajić, On methods for fire risk analysis, Procesing '16, SMEITS, Belgrade 2016.

[2] Blagojević M., J. Ristić, Đ. Simić, Sistemi za otkrivanje i dojavu požara, Fakultet zaštite na radu, Niš, 2004.

[3] Bujandrić, V., N. Bujandrić, Projektovanje protivpožarne zaštite, Vedeko, Beograd, 1996. 
[4] Vidaković M., B. Vidaković, Požar i arhitektonski inženjering 2008, Fahrenheit, Beograd, 2008.

[5] Erić, M., Protivpožarna i preventivno tehnička zaštita, Jel\&Mil, Čačak, 2003.

[6] Kadić, M., D. Sekulović, Zaštita od požara i eksplozija, Knjiga 2., Nova Prosveta, Beograd, 2004.

[7] Kaiser, J., Experiences of the Gretener Method, Fire Safety Journal $2(1979 / 80)$, str. 213-222, 1979.

[8] Sekulović, Z., M. Bogner, S. Pejović, Instalacije za gašenje požara, ETA, Beograd, Srbija 2012.

[9] Sekulović, Z., M. Damnjanović, M. Bogner, Preventivna zaštita od požara, ETA, Beograd, Srbija 2014.

[10] ***, Zakon o zaštiti od požara, Službeni glasnik Republike Srbije 111/09 i 20/15, 2015.

[11] ***, Pravilnik o tehničkim i drugim zahtevima za utvrđivanje požarnog opterećenja i stepena otpornosti prema požaru, Službeni glasnik Republike Srbije 74/09, 2009.

[12] ***, Pravilnik o načinu izrade i sadržaju Plana zaštite od požara autonomne pokrajine, jedinice lokalne samouprave i subjekata razvrstanih u prvu i drugu kategoriju ugroženosti od požara, Službeni glasnik Republike Srbije 73/10, 2010.

[13] ***, Pravilnik o tehničkim normativima za zaštitu skladišta od požara i eksplozija, Službeni list SFRJ 24/87

[14] ***, SRPS TR19:1997 - Tehnička preporuka za građevinske tehničke mere zaštite od požara industrijskih objekata, Savezni zavod za standardizaciju Beograd, 1997.

[15] ***, SRPS TP21:2003 - Tehnička preporuka za zaštitu od požara stambenih, poslovnih $i$ javnih zgrada, Savezni zavod za standardizaciju Beograd, 1997.

[16] ***, SRPS U.J1.030:1976 - Zaštita od požara. Požarno opteréenje, Savezni zavod za standardizaciju Beograd, 1976.

[17] ***, SRPS U.J1.240:1994 - Zaštita od požara u građevinarstvu. Stepen otpornosti zgrade prema požaru, Savezni zavod za standardizaciju Beograd, 1976.

[18] ***, SRPS-EN1991-1-2:2012, Evrokod 1: Dejstvo na konstrukcije izložene požaru, Institut za standardizaciju Srbije, Beograd 2012

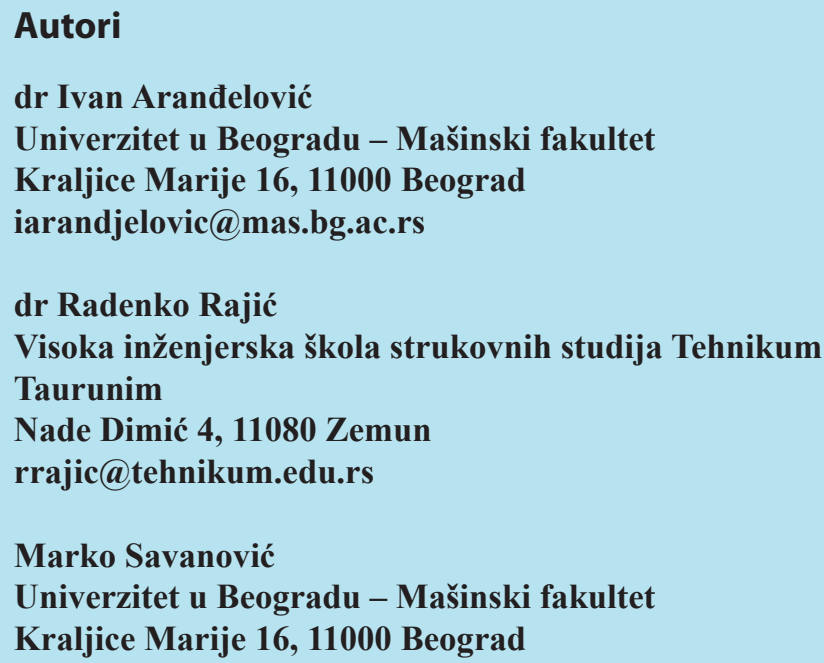

\section{Članski popust na izdanja SMEITS-a}

toplotna
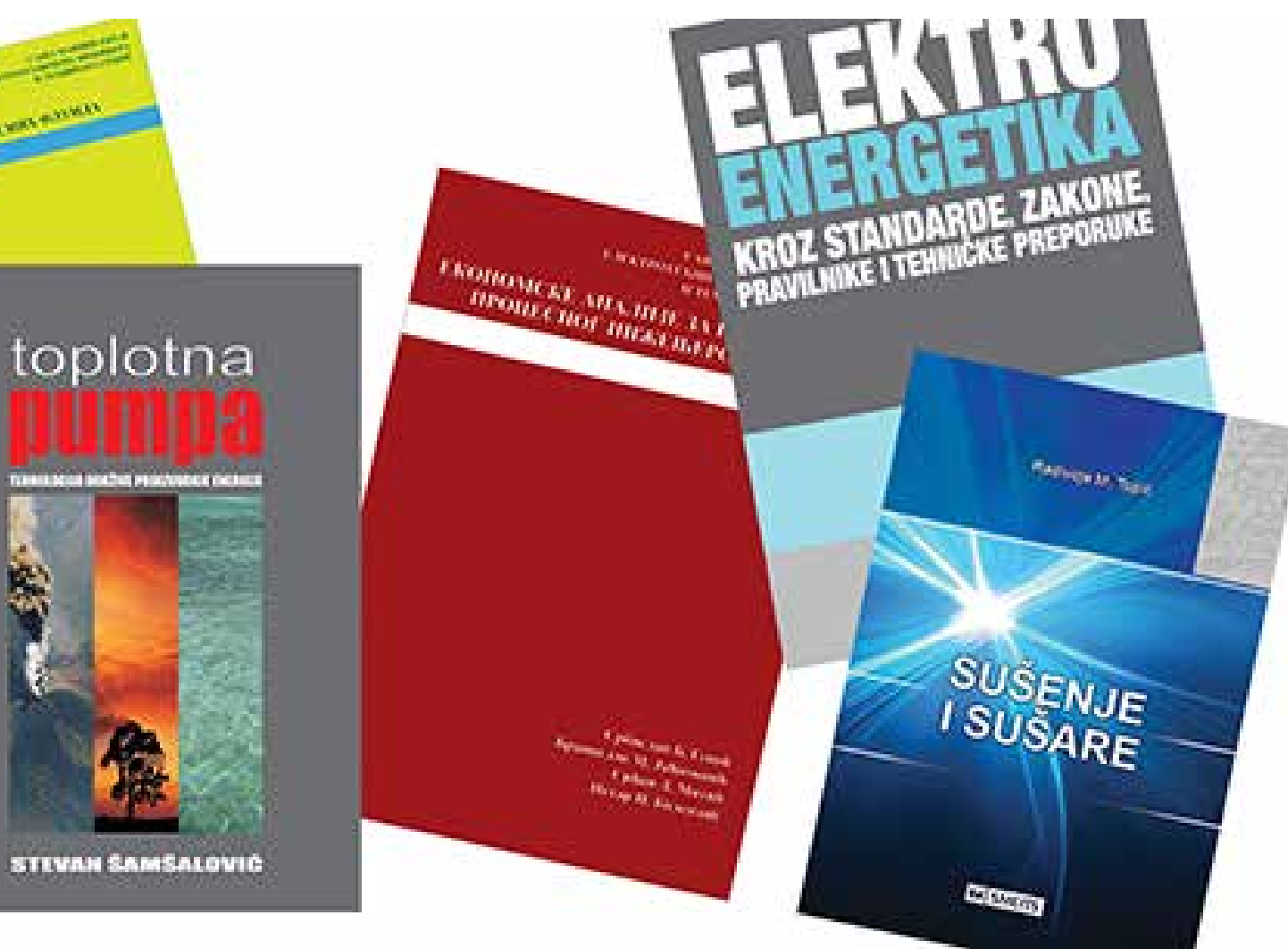